\title{
IMPACT OF COOPERATIVE LEARNING ON SPEAKING COMPETENCE OF 10TH GRADE STUDENTS IN PHO YEN HIGH SCHOOL
}

\author{
Nguyen Thi Thuy ${ }^{{ }^{*}}$, Nguyen Thi Minh Loan ${ }^{2}$ \\ ${ }^{I}$ Pho Yen high school, ${ }^{2}$ TNU - School of Foreign Languages
}

\section{ABSTRACT}

Over the past decade, cooperative learning has appeared as one of the leading approaches in speaking environments. In the teaching context at Pho Yen high school, there existed some problems for speaking skills that the researcher came across in helping the students to speak in the classroom such as shyness when expressing personal opinions, passivity in speaking activities, and so on. Therefore, the aims of the research is to evaluate cooperative learning's effects on the students' speaking competence and explore their attitudes towards this approach. There are forty 10th grade students, including 19 males and 21 females at 15 year old, taking part in the research. The authors used a combination of two data collection instruments: a speaking test and a questionnaire. The study has shown the significant improvements of students' English speaking performance after utilizing cooperative learning. Moreover, most of the students expressed a positive attitude towards applying cooperative learning and an interest in group work, which demonstrate that they believe in its positive effects. Besides, some suggestions were also proposed to reduce the shortcomings of using cooperative learning in English speaking classes to enhance the potentiality of this method and make it more interesting, meaningful and learning-centered.

Keywords: learner-centered; cooperative learning; speaking competence; $10^{\text {th }}$ grade students; speaking skills

Received: 23/9/2020; Revised: 15/10/2020; Published: 20/10/2020

\section{TÁC ĐỘNG CỦA HỌC TẬP HợP TÁC ĐẾN NĂNG LỰC NÓI CỦA HỌC SINH LỚP 10 TRƯời TRUNG HỌC PHỐ THÔNG PHỔ YÊN}

\author{
Nguyễn Thị Thủy ${ }^{{ }^{*},}$, Nguyễn Thị Minh Loan ${ }^{2}$ \\ ${ }^{I}$ Truờng Trung học Phồ thông Phổ Yền, ${ }^{2}$ Khoa Ngoại ngũ - ĐH Thái Nguyên
}

TÓM TẮT

Trong thập kỷ qua, học tập hợp tác được nhiều nhà giáo dục quan tâm nghiên cứu và ứng dụng như một trong những cách tiếp cận hàng đầu trong môi trường nói. Trong bối cảnh giảng dạy ở trường Trung học Phổ thông Phổ Yên, có một số vấn đề còn tồn tại đối với kỹ năng nói mà nhà nghiên cứu gặp phải trong quá trình giúp học sinh nói trong lớp học như việc ngại ngùng khi phát biểu ý kiến cá nhân, thụ động trong hoạt động phát biểu, v.v. Do đó, mục đích của nghiên cứu là đánh giá tác động của học tập hợp tác đối với năng lực nói của học sinh và khám phá thái độ của họ đối với phương pháp này. Đối tượng tham gia nghiên cứu là 40 em học sinh lớp 10, bao gồm 19 nam và 21 nữ đều có độ tuổi là 15 . Nghiên cứu sử dụng kết hợp hai công cụ thu thập dữ liệu: bài kiểm tra nói và bảng câu hỏi. Nghiên cứu đã chỉ ra những thay đổi đáng kể về khả năng nói tiếng Anh của học sinh so với trước khi sử dụng phương pháp học hợp tác. Hơn nữa, hầu hết các sinh viên đều bày tỏ thái độ tích cực đối với việc áp dụng phương pháp học hợp tác và quan tâm đến làm việc nhóm, điều này chứng tỏ rằng họ tin vào những tác động tích cực của nó. Bên cạnh đó, một số gợi ý được đưa ra để giảm thiểu những thiếu sót của việc sử dụng phương pháp học hợp tác trong các lớp học nói tiếng Anh nhằm nâng cao tiềm năng của phương pháp này và làm cho nó trở nên thú vị, ý nghĩa và lấy người học làm trung tâm.

Từ khóa: người học làm trung tâm; học tập hợp tác; năng lực nói; học sinh khối 10; kĩ năng nói

Ngày nhận bài: 23/9/2020; Ngày hoàn thiện: 15/10/2020; Ngày đăng: 20/10/2020

* Corresponding author. Email: nguyenthuytienganh@gmail.com
DOI: https://doi.org/10.34238/tnu-jst.3644

http://jst.tnu.edu.vn; Email: jst@tnu.edu.vn 


\section{Introduction}

As a means of communication, speaking is one of the most crucial skills to be improved and boosted [1]. Recent pedagogical practices in English language education have reflected the transformation from a teacher-centered learning model to a learner-centered learning model. In addition to applying methods and strategies for learner-centered approach, a promising method to traditional speaking instruction called the Cooperative Learning Approach should be applied to strengthen learners' speaking capacity. Ning [2] further claimed that this method works as the alternative way of teaching which allows students to have more speaking time and social interaction with others. Hence, cooperative learning gives students opportunities to interact and vary their learning styles so that they can develop their speaking skills naturally [3].

Over the past decade, cooperative learning has appeared as one of the leading approaches in speaking environments. One critical reason for this tendency is that a number of studies in different settings have suggested that language learners tend to achieve higher academic performance, self-esteem and greater comprehension when they are involved in cooperative group activities [4].

Rather than working individually, cooperative learning method can be achieved through interdependent tasks and activities. This feature makes cooperative learning better for students' achievements compared to conventional methods. It is clear that while students who work individually tend to compete with their peers to gain higher scores and other rewards, cooperative learning allows success and achievements for all members. Different from individual tasks, cooperative learning boosts competition among different groups which can be a solution for various problems.

In the teaching context at Pho Yen high school, there existed some problems for speaking skill that the researcher came across in helping the students speak in the classroom. Inhibition was the first problem that the students encountered in class. They were worried about making mistakes and afraid of being criticized by other people while speaking. They were also ashamed of the other students' attention towards themselves. The second problem in the speaking class was that students are still passive in participating, especially working in small groups with other students. During the process of teaching English at Pho Yen high school, the researcher also realized the problems in the students' group work. To begin with, some students were not very hardworking and inactive to cooperate in groups as well as take responsibilities while working in a team. Next, team members sometimes disagreed with each other, which led to stressful learning atmosphere. Besides, team members lacked skills to assign their tasks, resulting in inefficiency for teamwork activities. Furthermore, some students were still passive and lacked self-awareness when working in groups. Finally, sometimes, students who were assigned to be the leaders of their teams tended to follow a style that imposed their personal opinions rather than listening to ideas from other members.

Based on the current existing issues, this research was conducted to investigate the influence and effectiveness of cooperative learning approach to teaching speaking skill to see whether this method could enhance students' speaking competence or not. Therefore, the researcher decided to conduct the study "Using cooperative learning approach to enhance 10th grade students' English competence: An action research at Pho Yen high school".

\section{Methodology}

\subsection{The participants}

The researcher invited forty 10th grade students with the same age (15 years old), including 19 males and 21 females to take 
part in the research. They had been studying English as a compulsory school subject for at least 7 years. The students were between the elementary and pre-intermediate levels. By the time of the study, all of them had four years of learning English at secondary school. They were at the beginning of the second term.

\subsection{Data collection instruments}

The study used a combination of two data collection instruments:

- A speaking test

- A questionnaire

\subsubsection{Speaking test}

The speaking test was adapted from National Geographic Oral Placement Test. This test consisted of an interview based on conversational prompts to be presented by the interviewer, and was accompanied by Oral Assessment Guidelines to help interviewers determine the appropriate level of the student.

The selected students were required to answer thirty-three questions belonging to nine different topics from Elementary to Advanced level to check their speaking competence. The questions in each topic were divided into 2 types: close-ended question and open-ended questions. No grammar or other language skills were mentioned in the test. Each answer was assessed on a scale from 1 to 5, corresponding to English speaking ability from Low to Excellent. The test duration was about 20 minutes.

For the purpose of achieving reliable results, the researcher also invited another teacher of English at Pho Yen high school to assess the students' speaking competence. This teacher was trained to use the rubric of the test before the assessment. Throughout the rubric of the test, two examiners, including the researcher and invited teacher of English, assessed the speaking ability of the students. The contents of the speaking tests were recorded so that the examiners would be able to check the results of the test again. Mark allocation was 9 points in total, which meant 1 point for each item. This speaking test was employed as both the pre-test and post-test to measure the students' speaking competence.

Before the application of the intervention, the students in the class were given a speaking test as the pre-test. Ten weeks later, when the students finished 9 sessions, they were given the same speaking test as the post-test.

\subsubsection{Questionnaire}

The questionnaire which was used in this research was adapted from the questionnaire by McLeish [5].

The questionnaire gathered the participants' feedback relating to cooperative learning, including the following aspects such as benefits of using cooperative learning and attitudes of participants toward cooperative learning.

The questionnaire was designed in a mixed format, including 4-point Likert statements, close-ended questions and open-ended questions. The questionnaire was divided into 4 sections. In section 1, students answered two questions about general information (full name and gender). In section 2, the researcher designed some multiple-choice questions to find out the current situations about group assignments or activities at Pho Yen high school. In section 3, students indicated how much they agreed with fourteen statements on a scale from 1 to 5 , corresponding to attitude towards using cooperative learning in English speaking class from strongly disagree to strongly agree. In section 4, the researcher designed open-ended questions to collect recommendations from students about group activities. The questionnaire was given at the end of the intervention.

\subsection{Procedure of data collection}

\subsubsection{Planning}

In this step, the researcher collected baseline data related to the students' speaking problems through observation and classroom interaction. On the basis of the initial data 
about the speaking problems collected and analyzed, an action plan was developed. The researcher planned and prepared what materials that would be used, how to use cooperative learning approach to teach speaking lessons, and how long this intervention would take. Besides, the teacherresearcher explained to the headmaster the envisaged process during the research to gain his understanding and cooperation. Finally, the researcher designed lesson plans using the cooperative learning model.

\subsubsection{Action}

In the second stage, the teacher-researcher tried out the ideas of cooperative learning approach in teaching speaking.

The intervention lasted 9 weeks from March, $23^{\text {rd }}$ to May, $24^{\text {th }} 2020$. In the first 5 weeks, the students studied English speaking lessons from unit 9 to unit 13 via the online application named "Zoom" due to Covid epidemic. From unit 14 to unit 16, the students joined English speaking classes with applying cooperative learning in the classroom at Pho Yen high school.

The students learned English speaking periods via cooperative learning through seven phases:

Phase 1: Delivered goals and Student motivated

In this phase, the teacher told about the objectives of the speaking lesson, and motivated the students in the speaking lessons.

\section{Phase 2: Given/ Delivered Information}

In the speaking lessons, class presentation by the teacher was via whole-class instruction related to vocabulary, grammar, or replays of audiovisual materials.

Phase 3: Student organizing into study group

All students were divided into different groups of 5 people (mixed from their achievement, gender, and so on) to work with on alternative weeks during the study duration, and gave each group a different number. The students in a group letter off A, B, C, etc. Therefore, each person had a specific and distinct number and letter (such as 3B). All students were responsible for the individual learning or in groups, and they were in discussions regarding the teacher's lessons and were sure every member of the group would understand the delivered material.

Phase 4: Giving tasks

The teacher gave tasks toward groups for doing by member. The students were encouraged to work together the task, and they coordinated their efforts to accomplish the tasks assigned by the teacher.

Phase 5: Guiding/ Helping groups on work and study

The teacher gave instructions toward the group members who had understood. After that, these students could help their friends in the group to understand the material. The teacher asked their students to encourage his teammates to express opinions, which led to less stressful atmosphere. The group members actively co-ordinated their efforts, ensuring that others had the opportunity to contribute, provide help and assistance when it was needed, and encourage others' efforts. The teammates worked on the given task within a given time limit. The task was based on the textbook learning materials, or a team assignment to be completed within one week. In terms of assignment, the teammates needed to reach an agreement in advance when and where they meet, how they assign the tasks to different members according to their strengths, interests and competence and add some other learning resources if needed.

\section{Phase 6: Evaluation}

The teacher chose a letter and all the students in every group by the same letter stood and answered the questions which had been given to all the students. The students' performance was evaluated following the pre-set criteria and the teacher gave the students some 
suggestions and grades. After that, other students were selected to represent and report to the class.

\section{Phase 7: Giving Appreciation}

The teacher looked all the way for appreciating the students' efforts individually and by group.

\subsubsection{Observation}

During the third stage, the teacher-researcher concentrated on gathering information about the actions taken carefully and systematically. In this study, the researcher used the speaking test and questionnaire as the data collection instruments.

Before starting the intervention, the students did the pre-test. From the results of the pretest, the researcher determined the levels of the student before applying cooperative learning in the speaking class.

At the end of the intervention, the post-test of oral performance and the questionnaire to investigate the students' attitude towards cooperative learning would be administered to the students.

\subsubsection{Reflection}

In this stage, based on the data analysis, the researcher made reflections about the action implementation. The reflection of the actions indicated the success or the failure of the action research. Therefore, the researcher would have recommendations for both teachers and students.

\section{Results and discussion}

\subsection{Results of the speaking test}

As seen from Table 1, the pre-test scores ranged from 4.0 to 5.8 with the mean of 4.880. It means that students' speaking competence before applying cooperative learning was at poor levels whereas the scores of the post-test which applied cooperative learning activities ranged from 4.0 to 7.2 with the mean of 5.565. This proved that there was a significant difference between mean scores of the two tests. The students' speaking performance had been improved considerably. This significant improvement could be attributed to the effectiveness of cooperative learning applied in the study.

\subsection{Data from the questionnaire for students}

Forty participants of 10th grade students at Pho Yen high school completed the questionnaire to investigate their attitudes toward the use of cooperative learning in speaking classes. In order to facilitate the analysis, the 5-level statement of perception in the questionnaire - Strongly Agree, Agree, Undecided, Disagree, Strongly Disagree were regrouped into three main categories: Disagree, Undecided and Agree.

Table 2 shows the result of the questionnaire regarding the students' attitude toward using cooperative learning in speaking classes. From table 2, it is clear that $70 \%$ of the students agreed that they achieved more within the group than on their own, $12.5 \%$ remained neutral while $17.5 \%$ disagreed. $85 \%$ of the students agreed that they willingly participated in group activities, $5 \%$ remained neutral, while $10 \%$ disagreed. $90 \%$ agreed that cooperative learning improved their attitude to work, $7.5 \%$ renewed neutral, while $2.5 \%$ disagreed. $82.5 \%$ agreed that cooperative learning enhanced socialization, $12.5 \%$ remained neutral, while $5 \%$ disagreed.

Table 1. Descriptive statistics of the pre-test and post-test scores

\begin{tabular}{cccccc}
\hline & N & Minimum & Maximum & Mean & Std. Deviation \\
\hline Pre-test & 40 & 4.0 & 5.8 & 4.880 & 0.4659 \\
Post-test & 40 & 4.0 & 7.2 & 5.565 & 0.8350 \\
Valid N & & & & & \\
(listwise) & & & & & \\
\hline
\end{tabular}


Table 2. Students' attitude toward using cooperative learning

\begin{tabular}{llccc}
\hline & \multicolumn{1}{c}{ Statements } & Agree & Undecided & Disagree \\
\hline 1 & When I work together, I achieve more than when I work alone. & $70 \%$ & $12.5 \%$ & $17.5 \%$ \\
2 & I willingly participate in cooperative learning activities. & $85 \%$ & $5 \%$ & $10 \%$ \\
3 & Cooperative learning can improve my attitude towards work. & $90 \%$ & $7.5 \%$ & $2.5 \%$ \\
4 Cooperative learning helps me to socialize more. & $82.5 \%$ & $12.5 \%$ & $5 \%$ \\
\hline
\end{tabular}

Table 3. The students' views of using cooperative learning

\begin{tabular}{llccc}
\hline & \multicolumn{1}{c}{ Statements } & Agree & Undecided & Disagree \\
\hline 5 & Cooperative learning enhances good working relationships & $80 \%$ & $12.5 \%$ & $7.5 \%$ \\
& among students. & $87.5 \%$ & $2.5 \%$ & $10 \%$ \\
6 & Cooperative learning enhances class participation. & $75 \%$ & $15 \%$ & $10 \%$ \\
7 & Creativity is facilitated in the group setting. & $87.5 \%$ & $7.5 \%$ & $5 \%$ \\
8 & Group activities make the learning experience easier. & \\
\hline
\end{tabular}

Table 3 indicates that $80 \%$ of the students agreed that their working relationships have been enhanced through cooperative learning, while $7.5 \%$ disagreed. $87.5 \%$ of the students agreed cooperative learning could improve class participation, while $10 \%$ disagreed. $75 \%$ of the students agreed that when they studied with cooperative learning, creativity was facilitated, while $10 \%$ disagreed. $87.5 \%$ of the students agreed that group activities made the learning experience easier, while $5 \%$ disagreed.

\subsection{Discussion}

Based on the results of the statistical analysis reported in the previous sections, this section focused on the discussion of the major findings related to cooperative learning in learning English speaking.

As mentioned above, the researcher had been concerned in finding out the effectiveness of using cooperative learning to improve 10th grade students' English speaking competence. The researcher applied the cooperative learning to organize study activities in speaking lessons to the students of grade 10 at Pho Yen high school where she worked. During the time when the research was carried out, the researcher made her effort to search for the answers for the two research questions by analyzing collected data from the pre-tests, post-test, and questionnaire.
Through analyzing the data collected from the speaking tests, it can be seen that using cooperative learning had positive effects on the students' speaking performance. Thanks to sharing ideas and information among members in group work, students might feel more confident when speaking English, this helps them improve their speaking competence. It was clearly shown in the collected data from the pre-tests and post-test that there was a significant difference in the distribution of points in the pre-test and the post test. This proved that there was an obvious improvement of the participants' speaking competence after they had learned English speaking by applying cooperative learning. The above statistics implied that using cooperative learning in speaking lessons was effective in both short-term and long-term.

Through the questionnaire, it can be stated that the participants had positive attitudes, high perception and good behavior towards using cooperative learning in learning English speaking. Concerning about the attitudes of the students towards using cooperative learning in learning English speaking, most of the students participating in the study agree that using collaborative learning in learning to speak English in particular and in learning English in general helps them: achieve more in groups; improve work attitude; enhancing 
socialization; strengthening working relationships through collaborative learning; improve class participation; with creative conditions; have an easier learning experience. Most students in class $10 \mathrm{C} 1$ presented their positive attitudes towards the application of cooperative learning and their interest towards group activities, which proved that they believed in its positive effects.

In general, most of the students participating in the study exposed positive attitude towards cooperative learning used in English speaking lessons.

\section{Conclusions and recommendations}

\subsection{Conclusions}

As expected by the researcher, there were changes as a result of the actions. The changes were both in the way of thinking and in the behavior of the involved members. The changes were related to the following:

Firstly, it was undeniable that cooperative learning had a positive effect on the students' English speaking competence. At the second term of school year 2019-2020, 40 10th grade students had a chance to learn English speaking through cooperative learning under the researcher's specific instruction. Data from the score of the pre-test and post-test of the participants demonstrated that cooperative learning was beneficial to improve the 10th grade students' English speaking competence effectively.

Secondly, through the questionnaire and observation checklists, it can be seen that most of the students expressed a positive attitude towards applying collaborative learning and an interest in group work, which demonstrated that they believed in its positive effects.

In conclusion, the researcher would like to give some efficient suggestions on ways to improving the effectiveness of cooperative learning in studying English speaking. Hopefully, this study might be helpful for 10th grade students and teachers of English to develop English speaking competence.

\subsection{Limitations of the study}

Although the study has provided a comparatively detailed description of the cooperative learning in improving speaking competence of the 10th grade students, there are still some limitations of the study.

First, when implementing the action plan, some students were not aware of the importance of cooperative learning. Hence, some participants did not concentrate on the tasks, which made the speaking lessons noisy and some of them used mother tongue in the class.

Second, the study was carried out in a limited time of 11 weeks. The study would be more reliable if the research had been taken in a longer time. The longer time is a key factor creating the more success for students' speaking competence.

Third, the results were particular from one class (10C1) at Pho Yen Upper Secondary School. If the action research was implemented in more classes, the results of the study would be generalized to a larger population.

\subsection{Recommendations}

Based on the research results, some suggestions are referred to the English teachers of 10th grade of Pho Yen high school, and other researchers.

\subsubsection{The English teacher}

Teachers should have specific instruction, focusing on learning content and tasks when using cooperative learning to teach in English speaking lessons for students because they are not proficient to provide sufficient input. At the end of learning activities, teachers should concentrate on assessing and correcting students' mistakes to improve students' speaking competence in a timely manner.

In order to use cooperative learning proficiently in the classroom, teachers of English need to have regular update with specialized knowledge such as the theory and 
philosophy of cooperative learning methods of implementing cooperative learning activities. Cooperative learning activities can be effective when teachers have opportunity to work together and learn expertise and experience from each other. When teachers observe and contribute to each other's lessons, they can acquire and develop teaching strategies based on cooperative learning activities appropriate to their own situations.

The English teachers need to give more opportunities for the students to practice speaking in the class. The enjoyable and nonthreatening atmosphere, interesting media should also be made to make students more interested in the lesson. The teacher can use the activities such as think-pair-share, numbered head together, two stay two stay, and inside outside circle. When conducting the cooperative activities, the teacher should pay attention to the class management since in cooperative learning the students tend to move around the class to have a discussion with others.

\subsubsection{Other researchers}

This research focuses on improving the students' speaking skills using cooperative learning activities. There are still many activities that can be used to teach speaking.
For the other researchers, it is necessary to look for and try out other activities so that the learning activities will be more various. Furthermore, in doing similar research, the speaking materials and the speaking tasks could be modified based on the students' learning ability and interest.

\section{REFERENCES}

[1]. L. M. Leong and S. M. Ahmadi, "An analysis of factors influencing learner's English speaking skill," International Journal of Research in English Education, vol. 2, no.1, pp. 1-34, 2017.

[2]. H. Ning and G. Hornby, "The effectiveness of coop-erative learning in teaching English to Chinese tertiary learner," Effective Education, vol. 2, no. 3, pp. 112-129, 2010. doi:10.1080/19415532.2010.522792.

[3]. Y. A. Al-Sohbani, "An exploration of english language teaching pedagogy in secondary Yemeni education: A case study," International Journal of English Language and Translation Studies, vol. 1, no. 3, pp. 40-55, 2013.

[4]. A. Alam, M. Uddin, L. Hossain, and J. Hamra, "A study of physician collaborations through social network and exponential random graph," BMC Health Services Research, vol. 13, no. 1, pp. 1-14, 2013.

[5]. K. McLeish, Attitude of Students Towards Cooperative Learning Methods at Knox Community, 2013. [Online]. Available: https://files.eric.ed.gov/fulltext/ED506779.pdf [Accessed June 26, 2020]. 